\title{
CAUSES OF DOMESTIC VIOLENCE AGAINST MARRIED WOMEN: A SOCIOLOGICAL STUDY WITH REFERENCE TO KARACHI CITY
}

\author{
Rana Saba Sultan ${ }^{*}$ \\ Muhammad Yaseen ${ }^{* *}$ \\ Shahzaman ${ }^{* * *}$
}

\begin{abstract}
The aim and objective of this study is to analyse the causes of domestic violence against married women in Pakistan providing a complete picture of understanding on the phenomenon. This study was conducted in Safoora Goth, Karachi one of the oldest residential centre of Karachi where all local ethnic groups and class of people are inhabited. The factors included in the study were various reasons of domestic violence, nature of domestic violence, types of domestic violence, separation, and feeling of deprivation, husband drug addiction, partner violence, family system, family economic, ages of women and all other such related causes regarding domestic violence. The universe of the study was Safoora Goth, Karachi. The calculated sample size was 313 respondents in which researcher selected simple random sampling technique. The tool for the data collection was a questionnaire. Hypotheses were tested statistically among 5 hypotheses all have gotten accepted and showed the result as there are various causes of domestic violence. Thus, the researcher concluded that family system, family income and husband drug addiction are related to the domestic violence in a great deal.
\end{abstract}

Keywords: Domestic violence, women, deprivation, causes of domestic violence

\section{Introduction}

The violence against women has traditionally been a part of our social norms and values. This is an international issue which is being observed in the developed countries as well as the under developed countries on national, social, cultural, and societal level. ${ }^{1}$ The violence against women includes the dogmatic treatment and behaviour which not only harass them but keep them under the physical abuse. There lies a background of such behaviour and victimization which is historical, social and traditional. Violence against women is not taken as a social phenomenon but rather a part of traditional values and norms. Domestic violence is defined as intentional controlling or showing violent behavior by a person who is or was in intimate relationship with the victim. The controlling behavior may include physical abuse, sexual assault, emotional abuse, economic control, and/or social isolation of the victim. According to the centre for disease control and prevention, "any kind of social, physical, and psychological violence which is done with intimate partner relationship is called domestic violence". However, domestic violence is not limited to any class in society rather it is found in all classes.

"Rana Saba Sultan, Ph.D., Professor, Department of Sociology, University of Karachi

*** Muhammad Yaseen, Ph.D. Student, Department of Sociology, University of Karachi

${ }^{* * * *}$ Shahzaman, Ph.D. Student, Department of Criminology, University of Karachi

${ }^{1}$ Hayat, A.A. Women Victims of Social Evils, Institute of Security Management Karachi (2002). 
There are different kinds of domestic violence as: physical, psychological, sexual, verbal and economical. Mostly domestic violence is divided into two parts: physical violence and psychological violence. Physical violence means threatening, scratching, beating, slapping, or using weapon against someone, or burning etc. ${ }^{2}$ In other words physical violence could evidently be seen, psychological violence includes isolating partner, prohibiting her from job, stopping her to meet others, critiquing, abusing, restricting from others' help, leaving her in dangerous place alone and tying her in the home or a danger place etc. ${ }^{3}$ statistics show that globally one-third of woman is under the victimization of physical violence. Because of this, women aging from 15-44 years are under the risk of domestic violence. Extreme physical torture, hitting, abduction and raping ultimately result in breast cancer in majority of women. ${ }^{4}$ According to a report from all over the world 200000 girls ages from 5-15 are sold annually in the name of marriage, and around 300000 girls experience domestic violence. One fourth of every woman faces violence during the pregnancy. ${ }^{5}$ According to UNISCO violence against women is such a societal act which results in according a lower status to the woman in the society.

Violence against women is one of the most important issues of women in Pakistan which restricts women from living a healthy and fuller life. The statistics and media reports have shown an increasing trend of violence against women. The prevalence of reported cases of violence against women in Pakistan has increased by 7 percent as compared to 2011. Among total number of VAW incidents, 3,153 cases were reported in Punjab, 1,027 in Sindh, 283 in Khyber-Pakhtunkhwa and 78 cases were reported in Balochistan. The monitored stories clearly revealed that younger and married women were more often a target of violence against women. The statistics identify below 18 years of age as most susceptible to violence. Around 59 per cent of the victims were below 18 years of age, 31 percent were 19-36 years old and 9 percent were over 36 years of age. ${ }^{6}$ In a male oriented society where the rate of discrimination with the woman is high, the women in such society will not succeed to gain its legal right and status and shall face deprivation with regard to various aspects in the life. In such society man plays various kinds of tactics in order to control the domestic decisions and issues. The aim is to keep the women in such an environment of fear in order to prevent the women to get consciousness about her significance and integrity. The easiest of all the methods is domestic violence for it and the man always practiced it. In fact domestic violence is the product of feudalistic society but still is being widely practiced in the industrial society as it was in the previous era. We can observe the causes of this phenomenon sociologically in feudalism. Pakistan is in a transitional stage from the feudalistic approach to the industrialist approach. So, Pakistan is such a country where the rate of domestic violence is on the increase by every comingday on the basis of social, economic and traditional perspectives. Government,

\footnotetext{
${ }^{2}$ Peterman, L, M. \& Dixon, C, G.. Domestic violence between same sex partners: implications for counselling. Journal of counselling and development. 81, (2003) pp.41-47.

${ }^{3}$ Yoshioka, M. R., Gilbert, L., El-Bassel, N., \&Baig-Amin, M. (2003). Social support and disclosure of abuse: Comparing South Asian, African American, and Hispanic battered women. Journal of Family Violence, 18, 171-180.

${ }^{4}$ Wednesday, Daily Jang, Karachi: 2008, $27^{\text {th }}$ February. Special edition on women day

${ }^{5}$ WHO;2008

${ }^{6}$ AWARE Girl. (2014). Survey on the perception and attitude of people towards domestic abuse in Pakistan. Special survey Report.
} 
media and human rights organizations mostly those organizations which are working for women rights are running campaigns as the proponent to the issue and for awareness in order to eradicate the domestic violence but the fact is that the rate of domestic violence beside all these efforts has not decreased yet. In this study the researcher highlighted those factors which provide the bases and making the rate of domestic violence higher in the society.

\section{Literature Review}

Dillard has presented four perspectives in his social psychological theory. According to him in the first perspective of frustration aggression theory, individuals show aggression due to any mental imbalance and develop tendency of aggressive behaviour. In his second theory of deviant behaviour Dillard elaborates that those who possess deviant behaviour in their early ages end up committing crimes, such individuals derive pleasure in inflicting pain agony onto others. In the third theory of self- attitude he deals with the individuals placed on the lower levels in the society, such individuals also resorts to violence and take pride in persecuting others in order to attain significance in the society. They commit rape, murder, kidnapping and violence against women. In his fourth motive attribution theory he states that individuals commit violence imitating or obeying others. ${ }^{7}$ Hamburger states that alcoholism, mental imbalance, various political and legal peculiarities e.g. tyranny, inhumane characteristics are related to domestic violence. ${ }^{8}$ According to Julian Rotter's Social Learning Theory, individuals wish to avoid negative consequences, while desiring positive results of effects. These circumstances are directly proportionate to the characteristics of the spouse, disturbances in daily life, disputes among family members, economic crisis, and violent and aggressive person. ${ }^{9}$ According to an study, wives are left due to the patriarchal family which is based upon the socioeconomic system. ${ }^{10}$ In our social system the husbands are deemed to be dominating, strong and self-sufficient, whereas, the wives are seen to be traditionally dependent. ${ }^{11}$ Wolfgang and Ferrancuti say, "...they are firm in their belief of culture of violence theory, and come up with the argument that how individuals restore their lives in a complex, crowded society and in their sub-groups to achieve a peaceful life". 12 According to Family System General Theory, human life is composed of social essence, devastated individuals avenge their deprivations for the reason they are deprived of their rights, authorities and they are victimised of inhumane and cruel behaviour. They are made to feel inferior complex e.g. confining women to their houses and restrict them to engage with anyone in talks and relations. Neil S Jacobson and John M. Gottman researched that violence between a couple is often due to enforce ones authority, it does not necessary to inflict any harm to other rather it only is to display ones strength and

\footnotetext{
${ }^{7}$ Dollard, J., Doob, L., Miller, N., Mowrer, O., \& Sears, R. (1939).Frustration and aggression. New Haven, CT: Yale University Press.

${ }^{8}$ Hamberger, L. K., \&Potente, T. (1994).Counseling heterosexual women arrested for domestic violence: Implications for theory and practice. Violence and Victims, 9(2), 125-137.

${ }^{9}$ Rotter, J. B. (1954).Social learning and clinical psychology.Englewood Cliffs. NJ: Prentice-Hall.

${ }^{10}$ Dobash, R. E., \&Dobash, R.P. P.Violence against wives. New York: Free Press, 1979).

${ }^{11}$ Ibid.

${ }^{12}$ Wolfgang, Marvin and Franco Ferracuti. (1967). The Subculture of Violence. London: Tavistock.
} 
leadership. ${ }^{13}$ Male always display his aggression to form his superiority over female. All relationships observe such attitude of male resulting domestic violence in the families. Domestic violence has long been an unsettled dispute and remains there due to the violent individuals. ${ }^{14}$ Chris Brown 1983 found that the dependency of women lies in the hands of men. Man satisfies the needs of women and he remains responsible to run the family. Whereas, women ascribe the role of a housewife to look after the domestic affairs. ${ }^{15}$ Jolie and Baumler 2005 explored that in Syria there were 2000 families who were found involved in domestic violence on the women. In those families $67 \%$ of the women were victimised of family punishments, $87 \%$ of the women of these cases faced physical violence, $06 \%$ of the women were restricted to meet friends and relatives. ${ }^{16}$ UNIFEM 2005 , conducted a research that found $21.8 \%$ of the women faced domestic violence in any form, and it was named as law and traditions, these included defamation, physical violence, sexual violence, theft, honour killings and kidnapping. In this $50-80 \%$ were the family members involved. Whereas, only $70 \%$ of the women were supported by their family members in the cases of sexual defamation. Rests of the family members have accused the women for such cases. 35\% of the women were honoured killed by their husbands. ${ }^{17}$ F.F. Fikri and L.I. Bhatti 1999 explored that 34 cases of physical violence were reported. In which $15 \%$ of the women were physically assaulted while in pregnancy and $72 \%$ of the women were physically assaulted when they were depressed. Indicators show that physical violence is the main cause for depression. Physical and psychological violence are the main causes for malnutrition in infancy. ${ }^{18}$ Faryal, Dr. P.H Junaid and A. Razzaq conducted a study to explore the maltreatment of the husbands towards their wives in Pakistan. Physical violence was related to three types of social and economic backgrounds. In the given population 176 married men remained with their wives in the wedlock for only 01 year. They were found harsh with their wives when they were interviewed. In the given time of one year $49.4 \%$ of the men were found to be physically violent on their wives. Physical abuse and piercing were reported to be $47.7 \%$. There were $55 \%$ of the male who remained victims of physical violence in their early ages. $65 \%$ of the male observed their mothers to be the victims of violence when they were children. Half of them believed that it is the birth right of the husbands to inflict physical violence on their wives. ${ }^{19}$

\footnotetext{
${ }^{13}$ Jacobson, N., Gottman, J., Waltz, J., Rushe, R., Babcock, J., \&Holtzworth Munroe, A. Affect, verbal content, and psychophisiology in the arguments of couples with a violent husband. Journal of Consulting and Clinical Psychology, (1994) 62(5), 982-988.

${ }^{14}$ Archer, John. Sex differences in physically aggressive acts between heterosexual partners: A meta-analytic review. Aggression and Violent Behavior, 7(4), (2002) 313-351

${ }^{15}$ Browne, A. (1987). When battered women kill. New York: Free Press.

${ }^{16}$ UNFPA and UNIFEM.United Nations. The Millennium Development Goals Report. (New York: United Nations. 2005)

${ }^{17}$ UNIFEM. Progress of the World's Women 2005, women, work and poverty. (New York: UNIFEM, 2005).

${ }^{18}$ Fikree, F. F., and L. I. Bhatti (1999) Domestic Violence and Health of Pakistani Women. International Journal of Gynecology\& Obstetrics 65:2, 195-201.

${ }^{19}$ Fikree, F., Junaid, Ph., \&Razzak,A . The behaviour of men and domestic violence in Pakistan. Department of Community Health Science; (Karachi: Agha Khan University, 2005).
} 


\section{Objectives of the Study}

$>$ To explore the social causes of domestic violence against married women

$>$ To investigate the economic causes of domestic violence against married women

$>$ To provide effective solution for the eradication of domestic violence against married women.

\section{Hypotheses}

$>$ Age of women is likely to be related with nature of domestic violence

$>$ Family system is likely to be related with domestic violence

$>$ Family monthly income is likely to be related with domestic violence

$>$ Husband's drug addiction is likely to be related with type of domestic violence

\section{Research Methodology}

The present study is exploratory and comprises of four segments to drive a method for analyzing the socio economic causes of domestic violence against married women. The four segments are, interview schedule, sampling, the data collection method, and statistical analysis of data. The universe of the present study is UC 13 of Gulshan-e-Iqbal Town. Researcher applied the simple random sampling technique after getting the list of households from Union Council office. After that lottery method was used to select the households in which every fourth household was the subject of the study. The sampling of the current study was 313 household of the UC 13 Safoora Goth Gulshan-e-Iqbal. And the tool for the data collection was a questionnaire which was consisted on 60 questions. And the questionnaire included close ended questions and open ended questions. And the data were analyzed statistically through the test of chi square test of independence.

\section{Major Findings and Discussion}

The aim and objective of this study is to analyse the causes and consequences of domestic violence against married women in Pakistan and provide a complete picture of understanding on the phenomenon.

This study provides information about domestic violence in which 18-45 years of women are included in the study as subject. However, the mean of the age was recorded 31.5. And the social classes of the group were analysed among which $13.7 \%$ of respondents' mother tongue was Urdu. $27.8 \%$ of respondents' mother tongue was Sindhi, $19.5 \%$ of respondents' mother tongue was Panjabi. $12.5 \%$ of respondents' mother tongue was Pashto, $23.0 \%$ of respondents' mother tongue was Saraiki and 3.5\% of respondents' mother tongue was other than mentioned above. In the other languages were Balochi, Brahvi, and Gujrati were included.

Religion is maligned for male dominant society and violence against women. It is seen as majority male members of the society interpret Islamic principles in their favour to 
victimize the women that makes a great number of women the victims. ${ }^{20}$ However, all over Asia e.g. China, Japan and India societal norms rest on the traditions that allow male to dominate against women, to an extent such in the case even in the West. From the present study $78.6 \%$ of respondents were Muslims. 3.2\% of respondents were Hindu, $16.6 \%$ of respondents were christens, and $1.6 \%$ of respondents were others.

According to human rights watch report the ratio of domestic violence is higher in middle lower class in Pakistan. Because of low level of education in rural areas violence against women is in higher rate. According to Aneta's research, increase of urban facilities and rate of higher migration from rural to urban areas has increased the rate of violence against women. Because the immigrant families from rural to urban areas include children, husband and wife, so no other family members to intervene in domestic violence and women are mostly victimized in violence. ${ }^{21}$ In present research $75.1 \%$ of respondents belonged to rural areas and $24.9 \%$ of respondents belonged to urban areas. And $34.2 \%$ of respondents' were illiterate. $13.4 \%$ of respondents were just primary pass, $11.5 \%$ of respondents were middle pass. $24.0 \%$ of respondents were matriculated, $12.8 \%$ of respondents were intermediate pass, while $3.5 \%$ of respondents were graduated and $0.6 \%$ of respondents were Master pass.

Economic freedom is very much necessary for equality of women. Fredric Engels told in this regard that women must be given equal job opportunities rather than equal salaries. (Engles, F). But present capitalism society has affected the status of women in job conditions as well as less salary. The present research describes majority of the respondents i.e. $55.9 \%$ were housewife. $16.9 \%$ of respondents were government servants, while $6.7 \%$ of respondents were private servants. $8.0 \%$ of respondents were doing selfbusiness and $12.5 \%$ of respondents were doing other than mentioned jobs. Most of them work in garment factories and these figures lead the Pakistan women economic status. Most of families have migrated from rural to urban areas as the present study $35.8 \%$ of respondents' family system was joint family and $64.2 \%$ of respondents' family system was nuclear family. Marriage is considered the basic and important institution in the society. The question regarding the marriage presents that $17.9 \%$ of respondents' age of marriage was 15 or less. $60.7 \%$ of respondents' age of marriage was $16-20$ years, while $21.1 \%$ of respondents' age of marriage was $21-25$ years and $0.3 \%$ of respondents' age of marriage was 26 or above years. And the nature of the marriage was $24.0 \%$ of respondents had love marriage, while $67.7 \%$ of respondents had arrange marriage and 8.3 $\%$ of respondents had watta satta marriage.

Mostly women were restricted to meet their relatives and families. As $35.8 \%$ of the respondents had no problem of going out from their home. 5.4\% of respondents were restricted by their husbands to go out of home without their permission, $14.7 \%$ of respondents were free to go out of home toan extent and $44.1 \%$ of respondents had no issue from their husbands to go out of home.

\footnotetext{
${ }^{20}$ Zaman, H. Saud Joseph, AfsanehNajmabad, ed. Family law and politics: encyclopedia of women and Islamic culture: 2. (2004) Brill.124

${ }^{21}$ The World's Women. Trends and Statistics. (New York: United Nations, 2000).
} 
According to a research in Karachi, the ratio of domistic violence was found to be $60 \%$, whereas, violence committed by the in-laws was found to be $15.3 \%$, against women. ${ }^{22}$ But in the present research $58.8 \%$ of the respondents have revealed that their husbands do violence upon them and $41.2 \%$ of the respondents are not the victims of violence by their husbands. Beside this $13.7 \%$ of the respondent's husbands' nature of violence was fractional/nominal. $22.0 \%$ of respondent's husbands' nature of violence was aggressive, while $23.0 \%$ of respondent's husbands' nature of violence was to the extent of cruelty and $41.2 \%$ of respondents were not the victims of violence by the husband. And $14.1 \%$ of respondents were victims of the psychological violence of husband, $22.4 \%$ of respondents were victims of physical violence of husband, while $22.7 \%$ of respondents were the victims of psychological and physical violence of their husbands and $40.9 \%$ of respondents thought that this was unnecessary question.

The psychological violence includes: $5.1 \%$ of respondents complained that their husbands were critical of their actions. $1.3 \%$ of respondents were made fun by their husbands, $2.6 \%$ of respondents were criticized by their husbands, while $12.5 \%$ of respondents were abused by their husbands and $13.4 \%$ of respondents were the victims of all kinds of psychological violence. And $65.2 \%$ of respondents did not face psychological violence from their husbands. And physical violence includes, $11.8 \%$ of respondents were slapped by their husband. $14.7 \%$ of respondents were punched by their husbands, $1.0 \%$ of respondents were burnt by their husbands, while $1.3 \%$ of respondents were cut with a sharp weapon by their husbands and $16.3 \%$ of respondents were beaten with stick or shoes and other such kind of things by their husbands.

The data shows that $24.0 \%$ of respondents felt acute sense of deprivation due to husband violence. $22.4 \%$ of respondents despite being the victims did not feel deprivation due to husband violence, while $12.5 \%$ of respondent felt deprivation to an extent due to husband violence and other $41.2 \%$ of respondents felt that this was unnecessary question while they do not face any violence from husband. Majority $43.0 \%$ of respondents were under the victim of violence on the complain of sister in law or mother in law in which $3.5 \%$ of respondents were victimize due to complain of sister in law or mother in law by their husband but $15.3 \%$ of respondents do not agree on this. While $12.1 \%$ of respondents were the victim of violence on the complaint of sister in law or mother in law and $12.1 \%$ of respondents believe that this is the root of fighting among the husband and wife. $1.6 \%$ of respondents were victim of violence of husband due to their unemployment. $15.0 \%$ of respondents were victim of violence of husband due to their serving food on time, $16.9 \%$ of respondents were victim of violence of husband due to not doing the assigned work and $6.4 \%$ of respondents were victim of violence of husband on the complains of children. $10.2 \%$ of respondents were victim of violence of husband due to doing the work which was prohibited by the husband, $4.8 \%$ of respondents were victim of violence of husband for hunching of bad character by their husband, while $2.2 \%$ of respondents were victim of violence of husband due to mother in law and $1.9 \%$ of respondents were victim of violence of husband due to other kinds of reasons. $10.5 \%$ of respondents husbands were addicted to drugs, while $87.2 \%$ of respondents husbands were not addicted to drugs and $2.2 \%$ of respondents did not reply to the question asked. $1.6 \%$ of the respondents

22 Azmat, Tehzeen and Khawaja: 2009 
husbands were addicted to charas. $4.2 \%$ of respondents husbands were addicted to heroin, $4.8 \%$ of respondents husbands were addicted to alcohol, while $1.9 \%$ of respondents did not know what type of drug their husband uses and $87.5 \%$ of respondents thought is unnecessary question. $48.7 \%$ of respondents husband did violence upon them in intoxicated condition and $51.3 \%$ of respondents husband did not do violence upon them in intoxicated condition. $5.1 \%$ of respondents husband did violence due to money, while $7.3 \%$ of respondent husband did not do violence due to money and $87.5 \%$ of respondents believe it is unnecessary question. $24.0 \%$ of respondents husband did violence during their pregnancy upon them, while $19.0 \%$ of respondent husband did not do violence during pregnancy upon them and $15.3 \%$ of respondents did not answer the question. $8.0 \%$ of respondents husband did violence during their pregnancy upon them aggressively, while $6.1 \%$ of respondent husband did violence during pregnancy upon them in hard nature and $10.2 \%$ of respondents husband violence during pregnancy was normal. And $15.0 \%$ of respondents did not respond to the question. $16.6 \%$ of respondents told about husband violence to get separation, while $39.0 \%$ of respondent did not show husband besides being victim of violence about separation and $44.4 \%$ of respondents told that this question is unnecessary. $32.6 \%$ of respondents told that they keep silent during violence of husband while $22.4 \%$ of respondents told they reply as it to their husband during violence and fight. $41.5 \%$ of respondents told that they do not fight with each other and $3.5 \%$ of respondents told they do other beside the mentioned while fighting.

The data indicates that $6.1 \%$ of respondents told that their husbands have doubts on them, while $89.5 \%$ of respondents told that their husbands have no doubts on them and $4.5 \%$ of respondents did not reply to the question. 3.8\% of respondents wished to suicide due to husband violence, while $93.6 \%$ of respondents did not wish to suicide due to husband violence and $2.6 \%$ of respondents often wished to suicide due to husband violence.

\section{Hypothesis No. 1}

$\mathrm{Ho}=$ Age of women is not likely to be related with nature of domestic violence. $\mathrm{H} 1=$ Age of women is likely to be related with nature of domestic violence.

Contingency table is showing relationship between Age of Women \& Nature of Domestic Violence

\begin{tabular}{|c|c|c|c|c|c|}
\hline \multirow{2}{*}{$\begin{array}{c}\text { Age of } \\
\text { Women }\end{array}$} & \multicolumn{4}{|c|}{ Nature of Domestic Violence } & \multirow{2}{*}{ Total } \\
\cline { 2 - 5 } 18 or less & Normal & aggressive & hard & No response & 22 \\
\hline \multirow{2}{*}{$19-24$} & $\begin{array}{c}5 \\
(3.02)\end{array}$ & $\begin{array}{c}6 \\
(4.85)\end{array}$ & $\begin{array}{c}6 \\
(5.06)\end{array}$ & $\begin{array}{c}5 \\
(9.07)\end{array}$ & 22 \\
\hline $25-30$ & 14 & $\begin{array}{c}5 \\
(4.85)\end{array}$ & $\begin{array}{c}6 \\
(5.06)\end{array}$ & $(9.07)$ & 98 \\
\hline
\end{tabular}




\begin{tabular}{|c|c|c|c|c|c|}
\hline $31-35$ & $\begin{array}{c}11 \\
(14.2)\end{array}$ & $\begin{array}{c}16 \\
(22.7)\end{array}$ & $\begin{array}{c}30 \\
(23.7)\end{array}$ & $\begin{array}{c}46 \\
(42.5)\end{array}$ & 103 \\
\hline $36+$ & $\begin{array}{c}7 \\
(9.34)\end{array}$ & $\begin{array}{c}11 \\
(15.0)\end{array}$ & $\begin{array}{c}11 \\
(15.6)\end{array}$ & $\begin{array}{c}39 \\
(28.0)\end{array}$ & 68 \\
\hline Total & 43 & 69 & 72 & 129 & 313 \\
\hline
\end{tabular}

Calculated value of chi-square $=26.2$

Degree of freedom $=12$

Table value of chi-square $=21.026$

The level of significance $=\mathbf{0 . 0 5}$

As the calculated value of chi-square is higher than its table value with degree of freedom 12 and level of significance is 0.05 so null hypothesis is rejected and alternate hypothesis is accepted, therefore relationship exists between the age of women and the nature of domestic violence. It means that women who marry in early ages and has no idea of their rights and duties are the victims of domestic violence. The rigid cultural traditions and wrong interpretations of religion are leading the early marriages which are the signs of silence from the women rights. This is widely observed that rigid cultural backgrounds and tribal customs are responsible for the early ages of women.

\section{Hypothesis No. 2}

$\mathrm{Ho}=$ Family system is not likely to be related with domestic violence.

$\mathrm{H} 1=$ Family system is likely to be related with domestic violence.

Contingency table is showing relationship between Family System \&Type of Domestic Violence

\begin{tabular}{|c|c|c|c|c|c|}
\hline \multirow{2}{*}{$\begin{array}{l}\text { Family } \\
\text { system }\end{array}$} & \multicolumn{4}{|c|}{ Type of Domestic Violence } & \multirow{2}{*}{ Total } \\
\hline & Physical & Psychological & Both & No response & \\
\hline Joint & $\begin{array}{c}30 \\
(15.7)\end{array}$ & $\begin{array}{c}28 \\
(25.0)\end{array}$ & $\begin{array}{c}10 \\
(25.4)\end{array}$ & $\begin{array}{c}44 \\
(45.8)\end{array}$ & 112 \\
\hline Nuclear & $\begin{array}{c}14 \\
(28.3)\end{array}$ & $\begin{array}{c}42 \\
(45.0)\end{array}$ & $\begin{array}{c}61 \\
(45.6)\end{array}$ & $\begin{array}{c}84 \\
(82.2)\end{array}$ & 201 \\
\hline Total & 44 & 70 & 71 & 128 & 313 \\
\hline
\end{tabular}

Calculated value of chi-square $=35.3$

Degree of freedom $=3$

Table value of chi-square $=7.815$ 


\section{The level of significance $=\mathbf{0 . 0 5}$}

As the calculated value of chi-square is higher than its table value with degree of freedom 12 and level of significance is 0.05 so null hypothesis is rejected and alternate hypothesis is accepted, therefore relationship exists between the family system and type of domestic violence. It means that domestic violence is widely observed in those families and households which have migrated from rural to urban areas. And these families mostly included husband, wife and children which sociologically has seen nuclear family. Over all the ratio of domestic violence in nuclear families as compared to the joint family is higher. Indeed, domestic violence in such nuclear families is due to no intervention of other families as their non-existence due to in-migrants from rural to urban areas.

\section{Hypothesis No. 3}

$\mathrm{Ho}=$ Family monthly income is not likely to be related with domestic violence. $\mathrm{H} 1=$ Family monthly income is likely to be related with domestic violence.

Contingency table is showing relationship between Family Monthly income \& type of Domestic Violence

\begin{tabular}{|c|c|c|c|c|c|}
\hline \multirow{2}{*}{$\begin{array}{c}\text { Family } \\
\text { monthly } \\
\text { income }\end{array}$} & \multicolumn{4}{|c|}{ type of Domestic Violence } & \multirow{2}{*}{ Tota } \\
\hline & Psychological & Physical & both & No response & \\
\hline $\begin{array}{c}10000 \text { or } \\
\text { less }\end{array}$ & $\begin{array}{c}11 \\
(7.69)\end{array}$ & $\begin{array}{c}8 \\
(12.3)\end{array}$ & $\begin{array}{c}21 \\
(12.9)\end{array}$ & $\begin{array}{c}16 \\
(23.1)\end{array}$ & 56 \\
\hline $\begin{array}{l}10001- \\
15000\end{array}$ & $\begin{array}{c}7 \\
(8.38)\end{array}$ & $\begin{array}{c}28 \\
(13.4)\end{array}$ & $\begin{array}{c}11 \\
(14.0)\end{array}$ & $\begin{array}{c}15 \\
(25.1)\end{array}$ & 61 \\
\hline $\begin{array}{l}15001- \\
20000\end{array}$ & $\begin{array}{c}6 \\
(9.20)\end{array}$ & $\begin{array}{c}11 \\
(14.8)\end{array}$ & $\begin{array}{c}16 \\
(15.4)\end{array}$ & $\begin{array}{c}34 \\
(27.6)\end{array}$ & 67 \\
\hline $\begin{array}{l}20001- \\
25000\end{array}$ & $\begin{array}{c}8 \\
(5.08)\end{array}$ & $\begin{array}{c}7 \\
(8.16)\end{array}$ & $\begin{array}{c}8 \\
(8.51)\end{array}$ & $\begin{array}{c}14 \\
(15.2)\end{array}$ & 32 \\
\hline $\begin{array}{l}25001- \\
30000\end{array}$ & $\begin{array}{c}6 \\
(5.77)\end{array}$ & $\begin{array}{c}6 \\
(9.26)\end{array}$ & $\begin{array}{c}7 \\
(9.66)\end{array}$ & $\begin{array}{c}23 \\
(17.3)\end{array}$ & 42 \\
\hline $30001+$ & $\begin{array}{c}5 \\
(6.87)\end{array}$ & $\begin{array}{c}9 \\
(11.0)\end{array}$ & $\begin{array}{c}9 \\
(11.5)\end{array}$ & $\begin{array}{c}27 \\
(20.6)\end{array}$ & 50 \\
\hline Total & 44 & 70 & 71 & 128 & 313 \\
\hline
\end{tabular}

Calculated value of chi-square $=43.7$

Degree of freedom $=15$

Table value of chi-square $=24.996$ 


\section{The level of significance $=\mathbf{0 . 0 5}$}

As the calculated value of chi-square is higher than its table value with degree of freedom 12 and level of significance is 0.05 so null hypothesis is rejected and alternate hypothesis is accepted, therefore relationship exists between the family income and the type of domestic violence. Economic statues of women as compared to men is much more better which is observed by the researcher another cause of domestic violence. Because poverty and mismanagement of domestic decisions and patriarchal system of family in such male dominant society ultimate results of violence against men. In such societies, economic status of women is so low due to less salary and unemployment. So, this leads to violence against women.

\section{Hypothesis No. 4}

$\mathrm{Ho}=$ Husband drug addiction is not likely to be related with type of domestic violence. $\mathrm{H} 1=$ Husband drug addiction is likely to be related with type of domestic violence.

Contingency table is showing relationship between Husband Drug addiction \& type of Domestic Violence

\begin{tabular}{|c|c|c|c|c|c|}
\hline \multirow{2}{*}{$\begin{array}{c}\text { Husband } \\
\text { drug } \\
\text { addiction }\end{array}$} & \multicolumn{4}{|c|}{ type of Domestic Violence } & \multirow{2}{*}{ Total } \\
\cline { 2 - 5 } & Psychological & Physical & both & No response & \\
\hline Yes & $\begin{array}{c}11 \\
(4.64)\end{array}$ & $\begin{array}{c}9 \\
(7.38)\end{array}$ & $\begin{array}{c}5 \\
(7.49)\end{array}$ & $\begin{array}{c}8 \\
(13.5)\end{array}$ & 33 \\
\hline NO & $\begin{array}{c}32 \\
(38.4)\end{array}$ & $\begin{array}{c}60 \\
(61.1)\end{array}$ & $\begin{array}{c}65 \\
(61.9)\end{array}$ & $\begin{array}{c}116 \\
(112.0)\end{array}$ & 273 \\
\hline No response & $\begin{array}{c}1 \\
(0.984)\end{array}$ & $\begin{array}{c}1 \\
(1.57)\end{array}$ & $\begin{array}{c}1 \\
(1.59)\end{array}$ & 7 \\
\hline Total & 44 & 70 & 71 & 128 & 313 \\
\hline
\end{tabular}

Calculated value of chi-square $=14.4$

Degree of freedom $=6$

Table value of chi-square $=12.592$

The level of significance $=\mathbf{0 . 0 5}$

As the calculated value of chi-square is higher than its table value with degree of freedom 12 and level of significance is 0.05 so null hypothesis is rejected and alternate hypothesis is accepted, therefore relationship exists between husband drug addiction and the type of domestic violence. It means that drug abuse is an ultimate sign and cause of domestic violence. Because those husbands who uses drug has widely been observed and found using physical violence on their wives. Researcher mostly found that their husbands use alcohol, heroin and charas and inflict violence upon their partners cruelly. So, there is a direct relation between drug use and domestic violence. 


\section{Conclusion}

Domestic violence is a phenomenon that remains prevalent with a woman throughout her life. Women are the victim of domestic violence all over the world. The researcher tried to put a detailed glance over all causes of domestic violence in Karachi under this study. From the study we have come to know that many facets of the domestic violence are like a tale which was included in the research. This study justifies that domestic violence is not limited to one group or class rather it is a traditional behaviour which exists. This is affecting sociocultural values in women life from the past and has a historical background. The base lies in the perception that male think that woman is the property of him and he only uses woman for sexual desires. And to fulfill all the wishes and desires he looks toward her. To maintain the ownership and to enslave her, the man uses violence for control. Psychologically human believes that under the fear anyone can be enslaved. Because of this man does not want to lose someone, he furthers his legacy in terms of heirs and sexual desires at any cost. Therefore the male uses domestic violence to keep control over the female and uses various types of psychological and physical violence.

Domestic violence inflicts various negative impacts on women's life that make them suffer physically and psychologically, it may also include life threatening or chronic diseases and impairments. Human rights and women rights campaigns of awareness had increased the rate of domestic violence. Men with the awareness among women regarding domestic violence and their rights had changed the method and level of violence with the passage of time. Because men would not want to lose someone who fulfills his sexual desires and produce his heirs at any cost. In order to reduce the rate of domestic violence in the society we need strong policies and their implementation as well as bring changes in the educational institutions. We should provide such education that must change the psyche of the growing children. We need to take all institutions in this regard to change the thought process and behaviour of masses.

\section{Recommendations}

$>$ Legislations to determine the proper age for the marriage should be made and implementation of laws must be imposed directly. And marriages of minors should be banned; the violators should be severely punished to discourage the practice.

$>$ Female education must be accessible to every girl, courses and chapters of rights and awareness to eradicate domestic violence should be included at all levels of education.

$>$ Reporting cells should be made on community level and their staff should be female to register the violence.

> School level and college level texts books should include the chapters of laws of marriage, inheritance and harassment in order to aware the people for women rights.

$>$ Non-governmental organization should run mass campaign in community level 
for the awareness and reduction of domestic violence level at all levels.

$>$ Religious leaders should play a role in order to interpret the correct message of religious point regarding women rights, declarations from both the spouses with regard to the understanding of main points of family rights and domestic violence should be taken at the time of Nikkah.

$>$ Family courts should provide prompt and swift justice in disputes of family matters.

The networks of women rights and human rights be fully accessible to every individual in every community, news slides and tickers should be played on all TV channels to educate the audiences. 